Journal of Nepal Geological Society, 2019, vol. 58 (Sp. Issue), pp. 39-52

DOI: https://doi.org/10.3126/jngs.v58i0.24572

\title{
Sequence stratigraphic analysis of the Surma Group in X Gas Field, Surma Basin, Bengal Delta
}

\author{
*Afroza Parvin, A. S. M. Woobaidullah, and Md Jamilur Rahman \\ Department of Geology, University of Dhaka, Dhaka-1000, Bangladesh \\ *Corresponding author: ap13geo@hotmail.com
}

\begin{abstract}
This study builds a high-resolution sequence stratigraphic framework for the Surma Group in the X Gas field. At first, electrofacies and depositional sequences were interpreted from wireline logs. Then, the field wide configurations of these sequences have been identified in seismic using reflection terminations (offlap, onlap, toplap and downlap relationship). Finally, wireline log and seismic interpretations were integrated to establish sequences stratigraphic framework in the Surma Group.

Electrofacies analysis has revealed four major facies associations namely: (i) Bell shaped fining upward facies corresponds to retrogradational shoreface to tidal flat deposits, (ii) Funnel shaped coarsening upward facies corresponds to progradational shoreface to tidal flat, (iii) Cylindrical aggradational facies interpreted as stacked channel and (iv) Symmetrical or Bow shaped facies corresponds to heterolithic unit. The succession of Surma group of about $3100+\mathrm{m}$ has been divided into twelve depositional sequences. With exception of depositional sequence 1, 11 and 12, most of them are composed of three system tracts: sandy lowstand system tract, shaley transgressive system tract and heterolithic to shaley highstand system tract. Repetitive occurrence of incised valley, shoreface sand as well as tidal channel sand separated by transgressive system tract shelfal mud resulted in sand-shale alternation in the Surma Group. The lower depositional sequences (up to sequence-6) are shale dominated and equivalent to the Lower Surma Group. The upper six sequences are sand dominated, have more channel incisions and sequence boundary representing the Upper Surma Group.
\end{abstract}

Keywords: Depositional sequences, System tract, Sequence boundary, Incised valley, Seismic sequence stratigraphy

Paper Received: 23 Dec 2018

Paper Accepted: 20 Mar 2019

\section{INTRODUCTION}

The Bengal Basin is one of thickest and potential hydrocarbon bearing sedimentary basin in the world occupying Bangladesh and parts of west Bengal, Assam and Tripura of India. Surma Basin is the Sub-basin of Bengal Basin located at the NE Bangladesh, which is one of the most important gas rich province and Mio-Pliocene Surma Group is the main hydrocarbon reservoir in this basin.

Considerable geological, geophysical and sedimentological database have been established during hydrocarbon exploration activities in this basin in the past few decades. Valuable contributions have been made by Holtrop and Keizer (1970); Hiller and Elahi (1988); Lietz and Kabir (1982); Khan et al. (1988); Reimann (1993); Alam (1993). Alam (1989) described the geology and depositional history of the Cenozoic Succession and Johnson and Alam (1991) have discussed the sedimentary and tectonic evolution of Surma Basin. Najman et al. (2012) worked on seismic sequence stratigraphy for the first time in Bengal Basin dividing the Tertiary stratigraphy into three megasequences. Then recently, Parvin et al. (2019) have identified the petroleum prospect of the Surma Group in the Sylhet Trough based on sequence stratigraphic interpretation. However, detailed sedimentary analysis leading to reconstruction of the paleogeographic setting and the depositional environment of Neogene sedimentary succession in the Eastern fold belt (including the Surma Basin) are rare (Alam, 1991, 1993; Alam and Ferdous, 1996). These previous works in the Surma Basin have yield lihostratigraphic and structural analysis along with the evolution of petroleum prospect. Neither of these work mentioned above was evaluated based on the detailed sequence stratigraphic analysis (3rd order depositional sequence) in relation to sea-level change in the Surma Group. Even, traditional stratigraphy of the basin is followed biasedly from the stratigraphy of Assam region proposed by Evans (1932) which is a case of over simplification (Brunnschweiler, 1980). In the traditional stratigraphy, Tertiary units are shown as isochronous although, these units resulted from southward progradation of a mega delta followed by an advancing river plain (Fluvial) front (Imam, 2013). Hence, they become progressively younger farther south into the Bengal Basin, recording the long term progradation of depositional environment of Ganges Bharamaputra Delta onto the Bay of Bengal passive margin (Alam et al., 2003). These complexities of the stratigraphy of the basin motivate to carry out the research work on sequence stratigraphic analysis of Surma Group at X field, which is main reservoir rock in the Bengal basin. The gas field is located at the Moulvibazar district near the eastern corner in the Surma Basin as shown in the Figs. 1 and 2. 
The primary objectives in this study were: (i) to carry out a detailed electrofacies analysis in Neogene clastics, (ii) to establish a sequences stratigraphic framework, and (iii) to interpret the origin of sequences in relation to sea-level changes in the Surma Group at the study area. This study helps to interpret the change in depositional environment, trends in sediment accumulation, erosion in the Surma group as well new prospect in hydrocarbon exploration. Sequence stratigraphy infer the changes in relative sea level and it consequence from the vertical and lateral variations of sediments. This approach provides new insights for both local and international exploration and exploitation strategy for hydrocarbon plays, for example, the study may shed light in the tidal deposits of regressive shelves that are yet to be well documented, which may be significant to oil companies for accurate stratigraphic prediction. It will provide much information in relation to suitable hydrocarbon plays in Sylhet trough.

\section{TECTONICS AND PALEO-DEPOSITIONAL ENVIRONMENT}

The tectonic framework of Bengal Basin is divided into three major tectonic zone: (1) the platformal shelf in the northwest, (2) a narrow NE - SW trending 'Hinge Zone', (3) the Bengal foredeep to the southeast (Shamsuddin and Abdullah, 1997) (Fig. 1).

The Surma Basin is located in the NE part of the Bengal foredeep. This foredeep is characterized by huge sedimentary thickness and divided into two major parts: (a) the ChittagonTripura Fold Belt (CTFB) to the east, and (b) the deep basinal area (Shamsuddin and Abdullah, 1997) which is composed of Sylhet Trough (Surma Basin), Faridpur and Hatia Troughs (Guha, 1978). Since this study deals with the Neogene (MioPliocene) Surma Group in Surma Basin X gas field, it is important to understand the early Neogene paleogeography of this part of the basin. The Surma Basin is separated from the Shillong Massif by the Dauki Fault to the north and gradually ascends toward the Hinge zone to the northwest. The basin is bounded on the east and southeast by the Chittagong-Tripura Fold Belt of Indo-Burma Ranges and open to the Bengal Foredeep in the south-west. The eastern part of the Surma Basin shows a series of N-S trending anticline and syncline, which were possibly developed due to Early to Middle Miocene collision between the Indian Plate and the Burma Plate (Hiller and Elahi, 1988). The studied Gas field comprises of one of these N-S trending anticline (Fig. 1).

The geological evolution of the basin began in the late Mesozoic time with the break-up of Gondwanaland and is still ongoing (Alam, 1989). Since the Bengal Basin took the shape of remnant ocean basin (Ingersoll et al., 1995) during Oligocene, the Surma Basin has been experiencing its own evolutionary history. By the early Miocene, the Himalaya and Tibet started to uplift very rapidly and a major uptrust movement of the Shillong Plataue along the Dauki Fault separated the Surma Basin from the stable shelf. Therefore, this basin became an active sediment depocentre. In the Eocene time, paleodepositional shelf was located on the Surma Basin when delta plain was farther north (Fig. 1). In early Miocene delta shelf edge shifted farther South and the study area became an upper shoreface to prodelta setting (Alam, 1995). During middle to late Miocene, Shelf edge shifted farther south and the Surma Basin became dominated by intertidal to delta plain setting. In Pliocene, it was become an active delta plain. It shifted southward and reached the present day shelf location.

The Surma Basin consists of maximum number of exposed Cenozoic litho-formations within the Bengal Basin. Among them Miocene to earliest Pliocene sediment of Surma Group was deposited in a large mud rich prograding delta system in response to western encroachment of Indo-Burma range along with rising Himalaya (Alam, 1993). Following Evan's (1932) stratigraphic scheme, the Surma Group is traditionally divided by many authors in Bangladesh into two units: a lower Bhuban and an upper Bokabil Formations (e. g., Holtrop and Keizer, 1970; Hiller and Elahi, 1988; Banerji, 1984). Johnson and Alam (1991) have interpreted the Lower Surma Group (i.

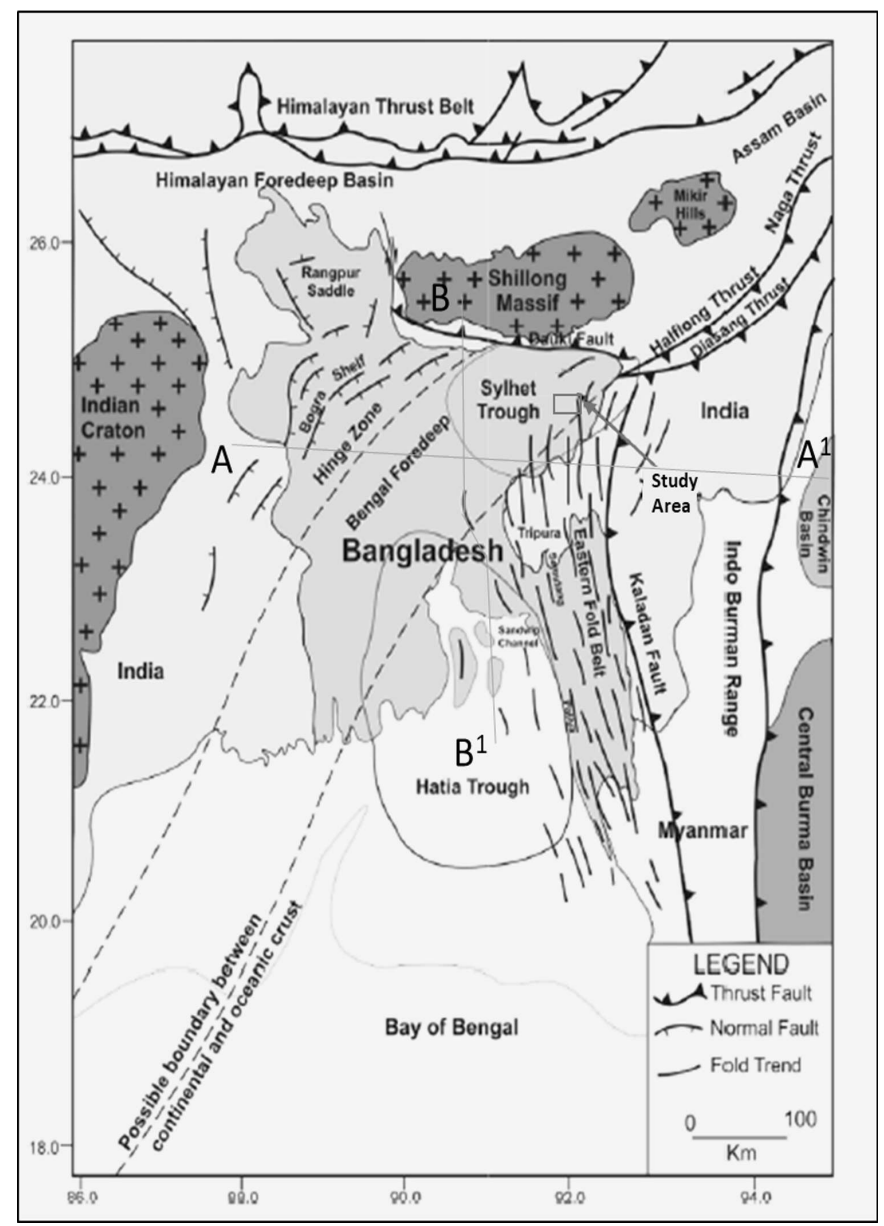

Fig. 1: Regional tectonic setting of the Bengal Basin and its adjoining area (modified after Mirkhamidov and Mannan, 1981; Abdullah et al., 2015; Khanam., 2017). The map shows the location of $X$ gas field in the Surma Basin. 
e., Bhuban) as prodelta to delta front deposits of a mud rich delta system. The sediments of the Upper Surma group represent the deposits of subaerial to brackish based on mudrock and pollen (Holtrop and Keizer, 1970). Based on comprehensive logging of the core samples from Sylhet Trough, Sultana and Alam, (2001) have interpreted the sediments of this group as deposits of shallow marine to tide-dominated coastal setting within a cycle of transgressive - regressive regime. The top of the group constitutes a predominantly shaley unit named as the "Upper Marine Shale" (UMS) (Holtrop and Keizer, 1970). Thickness of the Surma Group varies from $2700 \mathrm{~m}$ to over $3900 \mathrm{~m}$.

\section{METHODOLOGY}

Approaches have been conducted by a joint combination of well log data and seismic reflection interpretation. Both wireline $\log$ and seismic data were interpreted in the Schlumberger Petrel 2015 interpretation software. Orientation of seismic line and location of well were shown in the Fig. 2. The using reference schemes were Merkel (1979), Emery and

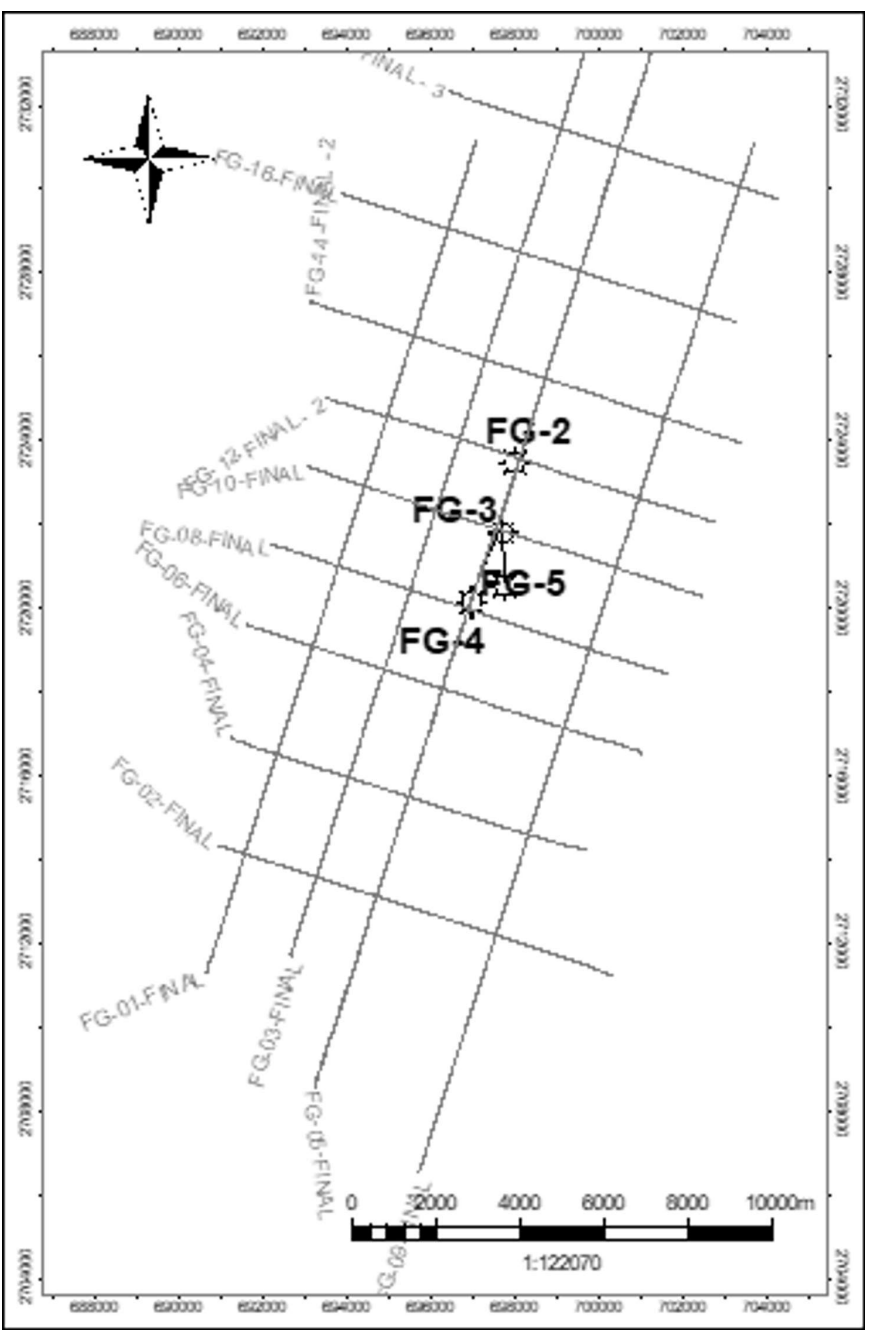

Fig. 2: Alignment of Seismic line and well location in the Fenchuganj gas field
Myers (1996) and Rider (2002) for wireline log and Mitchum et al. (1977), Vail et al. (1977), Van Wagoner et al. (1990), Emery and Myers (1996) and Posamentier and Allen (1999) for seismic interpretation.

\section{Delineation of electrofacies and depositional environment in well log}

The well log suits were displayed at a constant scale to enhance log trend and to aid the recognization of stacking patterns and parasequences-parasequences stack which gives rise to progradational, retrogradational or aggradational pattern. Serra and Sulpice (1975) correlated gamma-ray logs to grain size and classified log patterns based on the upper and lower contact. These patterns for Surma Group have been identified in this study. The companion logs (sonic, density/neutron, resistivity) displayed on the right tracks of gamma log show the response to changes in porosity and deflected opposite direction from gamma log. An upward decrease in radioactivity is accompanied by an upward decrease in shale content creating a funnel shaped response (coarsening upward) (Fig. 3). Conversely, an increase in shale content creates a bell-shaped pattern (fining upward). Symmetrical or bow shaped represents an initial coarsening upward followed by an increase in shale content upward. Cylindrical motif was also identified. The N$\mathrm{D}$ of coarser grained facies tracked each other closely or had little separation while shale interval had wide separation.

\section{Interpretation of key surfaces, system tract and depositional sequences}

In the wireline log, sequence boundary (SB) was placed at the sharp base of blocky or coarsening upward log trend (Fig. 3 ). Transgressive surface (TS) was interpreted as the surface between a coarsening upward trend and a fining upward trend. Maximum flooding surface (MFS) was picked at maximum gamma ray value, minimum resistivity, and sonic velocity value on the fining upward sequence. Then, their bounding system tracts were recognized to identify depositional sequence. Lowstand system tract (LST) was interpreted as an overall regressive stratigraphic unit bounded by a SB at the base and a maximum prograding surface (i.e., TS) at the top. Transgressive system tract (TST) was recognized as a retro gradational parasequence set bounded below a TS and above by a MFS whereas highstand system tract (HST) was recognized as prograding unit bounded below a MFS and above a SB or TS (if low stand system tract or sequence boundary is absent or eroded). Finally, each depositional sequence (SQ) was recognized as the combination of these three system tracts in order and bounded by sequence boundary at the base and top.

Afterwards, well correlation was achieved in petrel window with key surfaces (SBs, MFSs and TSs) to determine continuity or discontinuity of facies, configuration of system tract among four wells. Identified MFSs were flattened using Multi-horizon flattening technique in Petrel. MFSs were the best marker or datum on which correlation cross sections were hung. 


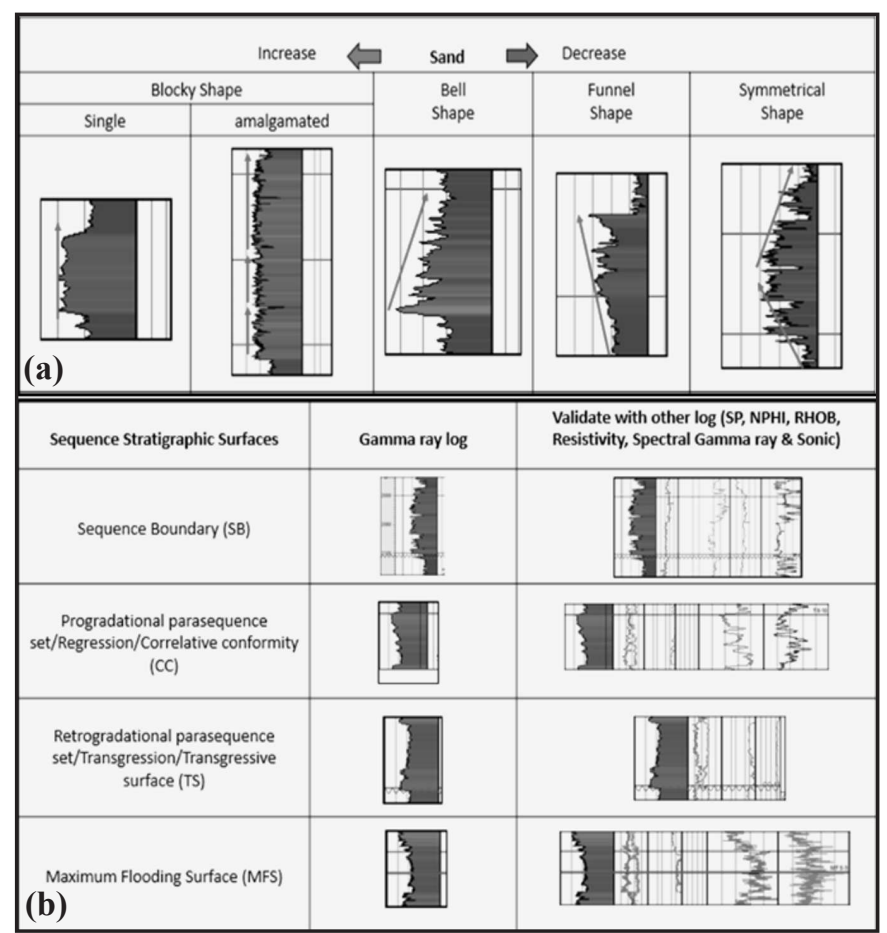

Fig. 3: Identification of (a) log motif and (b) stratigraphic surface using the data of this study

\section{Seismic interpretation}

Key surfaces were identified on seismic line based on distinct stratal geometry and relationship (Emery and Myers,
1996; Mitchum et al., 1977). Vertical exaggeration used during interpretation for dip line was $3 \mathrm{x}$ and for strike line was $5 \mathrm{x}$. Interpretations were done both in structural and flatten seismic lines. It was difficult to interpret subsequent transgressive surface because of the seismic resolution and area of coverage. That is why only sequence boundary and maximum flooding surface were interpreted on seismic lines. Naming of these surfaces was adopted from well-2 after making well to seismic tie.

Sequence boundaries were identified by truncation, onlap and toplap (Fig. 4). Maximum flooding surface was identified as the surface on which downlaping occurs indicating basinward progradation overlying an older marine surface.

\section{Well to seismic integration}

Both interpretations were integrated to subdivide the seismic sequences into their comprising system tracts so that their field wide configuration as well as petroleum system can be properly understood. To do this, the synthetic seismograms of well- 3 and well- 4 were generated by convolving the reflectivity derived from sonic and density logs with a ricker wavelet. Then, by comparing the stratigraphic surface point in well with the stratigraphic surface on seismic section, seismic interpretation was updated and seismic sequences were divided into system tract. As TS could not be identified on seismic, it is drawn on seismic at the TS point of well over lied on seismic (Parvin et al., 2019).

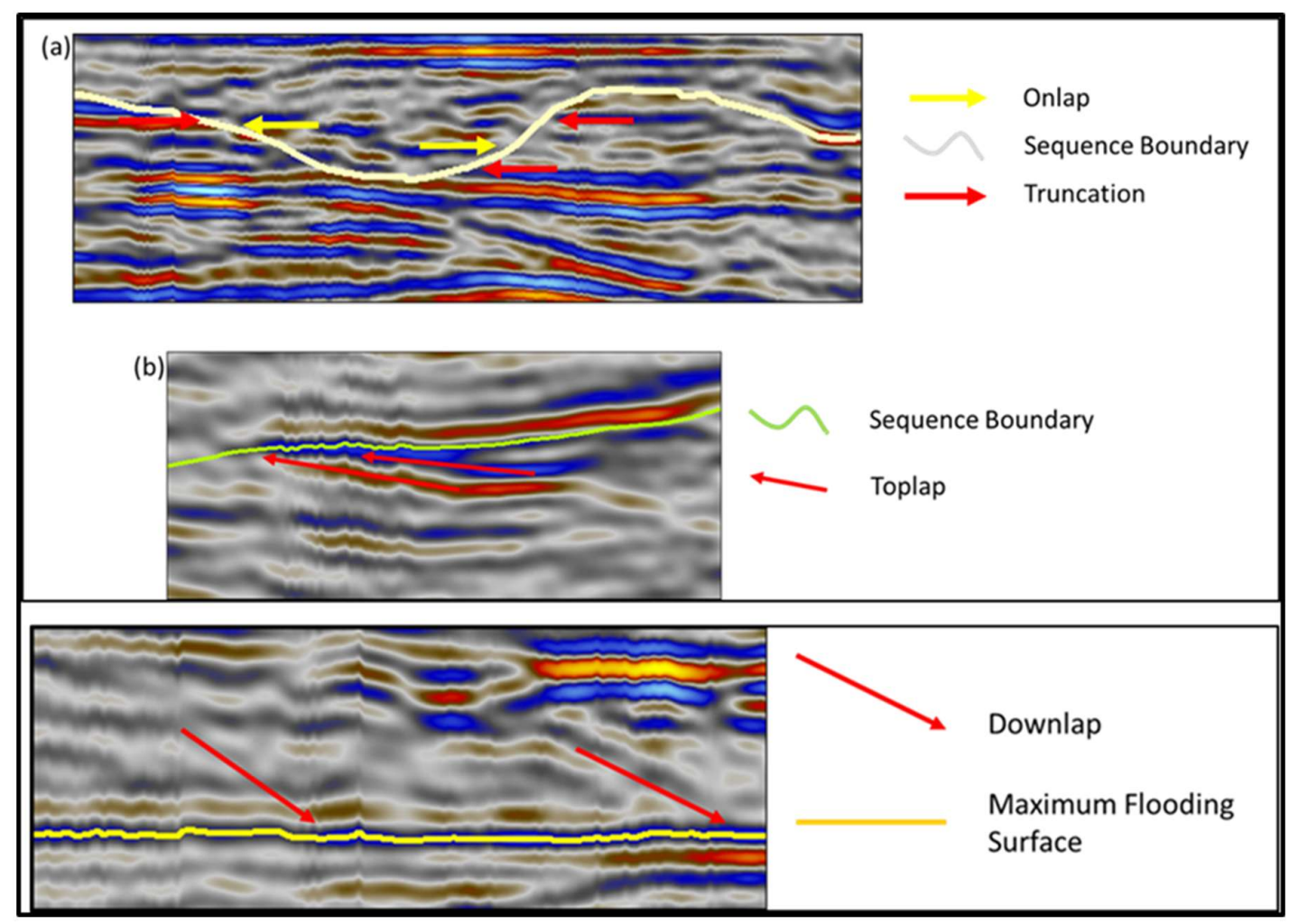

Fig. 4: Sequence boundary and maximum flooding surface identified using the data of this study 


\section{RESULTS}

\section{Electrofacies and depositional environment}

Four groups of log motifs were interpreted from the four well in X gas field named funnel shaped, bell shaped, cylindrical and bow shaped motif. Each electrofacies represents distinctive parasequence set in the Surma Group and associated with the changes in depositional environment with sea-level change as well as basin subsidence. The serrated nature of Gamma log in each shape is indicative of tide or wave activity. Among the four wells, only results of well-2 have been documented in Fig. 5 as an example.

Funnel shaped motif is most common pattern within the Surma Group. There are numbers of CU parasequences which lie one after another forming a large $\mathrm{CU}$ interval of about 250 $\mathrm{m}$ to $300 \mathrm{~m}$ thickness. This shape may be interpreted as tide dominated prograding estuarine deposits based on the presence of cyclic alternation of sandstones and mudstones in the Surma Group. CU facies has been also interpreted as progradational shoreface to tidal flat deposited during highstand time.

The Bell shaped motif corresponds to the increase of shale content upward. Average thickness of this motif ranges from $15 \mathrm{~m}$ to $50 \mathrm{~m}$. There are number of small $\mathrm{FU}$ parasequences lie one after another forming large FU sequences characterizing the facies as retrogradational shoreface to tidal flat deposits of transgressive period. In the most case, isolated small-scale cylindrical motifs are vertically accreted resulting a large cylindrical log shape. Average thickness of these facies ranges from 30 meters (in isolated channel) to even 280 meter (in accreted channel). This facies probably represents deltaic channel to shoreface sandstone facies. These blocky patterns are also common in sand filled incised valley deposited in the late lowstand time. The Bow motif shows a coarsening up trend overlain by a fining up trend without any sharp break resulting from waxing and waning clastic sedimentation rate. Its thickness ranges from $15 \mathrm{~m}$ to $175 \mathrm{~m}$. Small scale CU (funnel shape) at the lower part of this shape indicates sandstone lithofacies and bell shape (FU) at the upper part represent shaley litho-facies.

\section{Key stratigraphic surface, system tract and depositional sequence}

Among four wells in the studied field, well-2 is the deepest well and 11 sets of key surfaces (MFS, SB and TS) are interpreted in well-2. There are six key surfaces set interpreted in the well-3 and well-4 whereas four sets are interpreted in the shallowest well-5. Numbering of the key surface sets or depositional sequences was started from bottom to top in well-

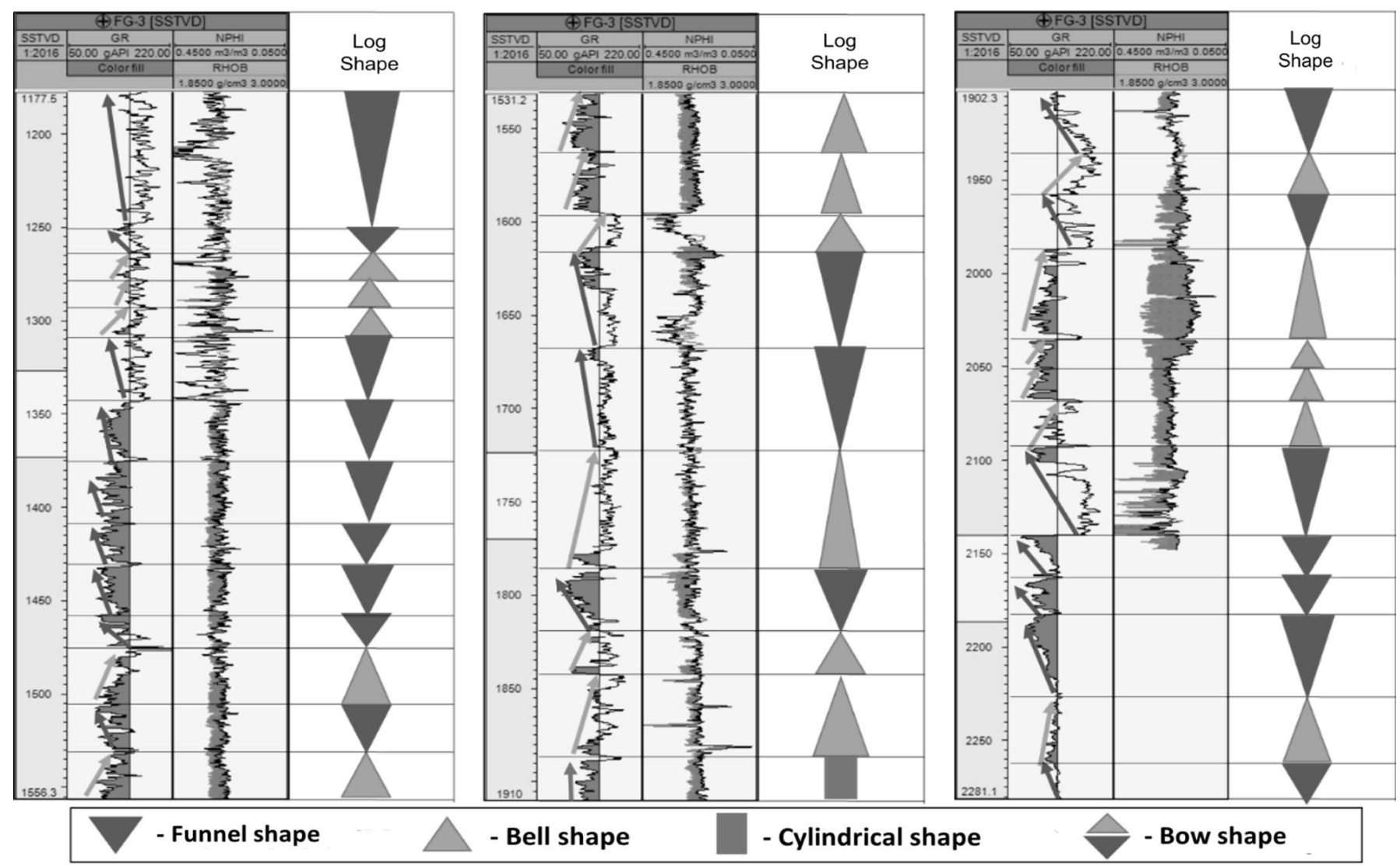

Fig. 5: Interpreted electrofacies in the Surma Group at well-2. For clarity of the figure, the resistivity and sonic log have been omitted here. 


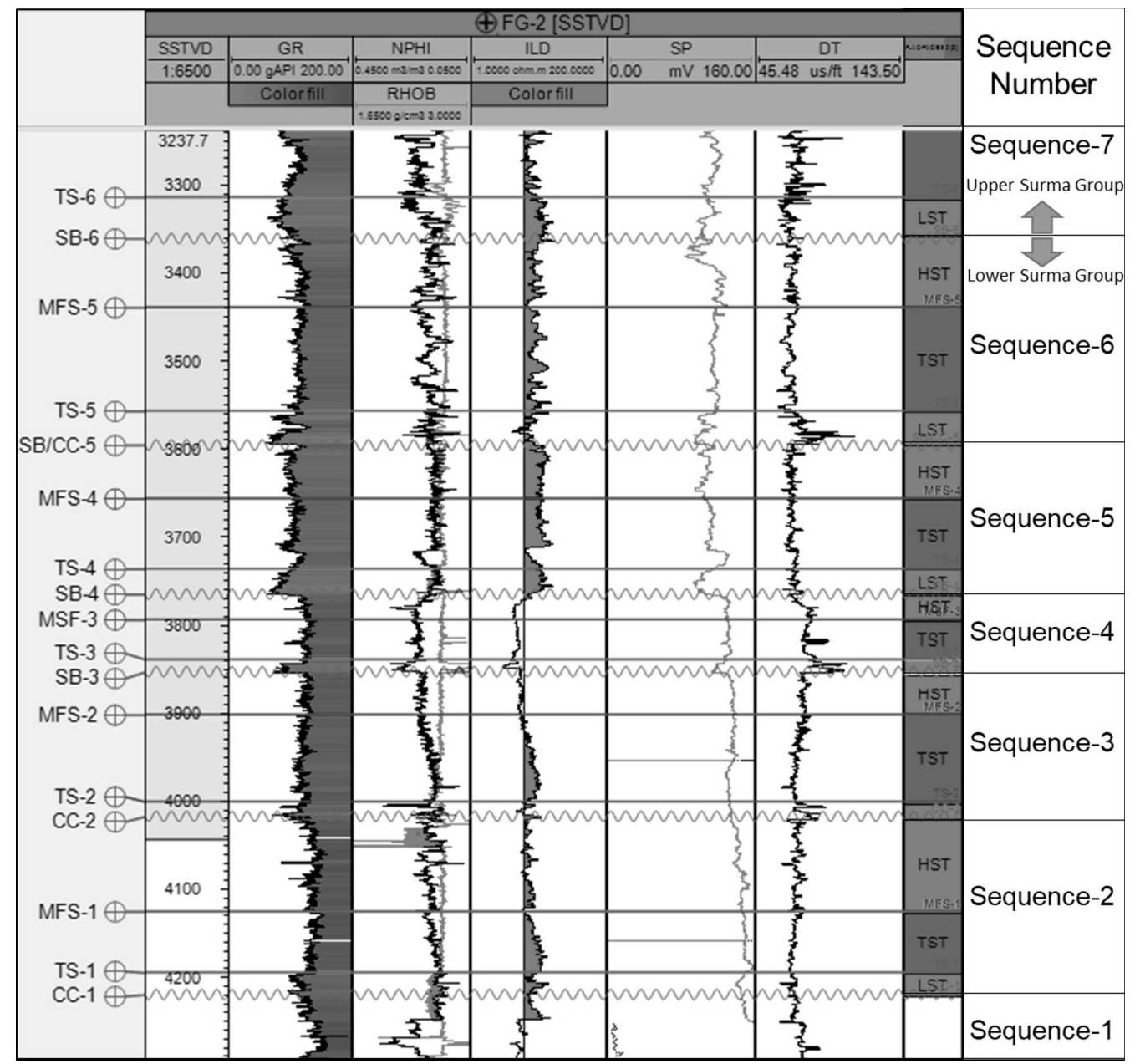

Fig. 6: Interpreted key stratigraphic surface and depositional sequence in the lower part of the Surma Group (LSTlowstand system tract, TST- transgressive system tract, HST- highstand system tract)

2. For other wells, their numbering was correlated with well2. Lower key surface sets (1-5) were interpreted only on well2 at depth ranges from $3350 \mathrm{~m}-4300 \mathrm{~m}$ (Fig. 6). They were not interpreted in well-3, 4, and 5 as these wells were not drilled below this depth. On seismic, they were also below resolution.

Twelve depositional sequences and the accompanying system tracts were interpreted based on the log motif in well2. Thickness of these sequence ranges from $88 \mathrm{~m}$ (SQ-4) to 720 $\mathrm{m}$ (SQ-7). Sequence SQ-1 is the deepest sequence bounded at the top by correlative conformity and it's lower boundary was not interpreted due to data limitation. In the sequence SQ-2, the both bounding surfaces are correlative conformities (CC1 and CC-2) whereas the upper boundary of SQ-3 is a sequence boundary SB-3 drawn at the base of a small sand body. This sand body comprises the LST of next sequence SQ-4 and from this sequence; all the sequences are bounded by sequence boundary. Over all, it can be seen that, upto sequences SQ-6, all the sequences are composed of fine grain sediments and their grain size increases upward from SQ-1 to SQ-6. In an individual sequence, most LST are composed of coarsening upward to blocky small sand to silt facies whereas TST and
HST are composed of shale to silty rock facies.

However, from the sequence SQ-7, all the sequences (SQ-7 to SQ-12) are composed of coarser grained rock facies (Fig. 7). LST of SQ-7 is composed of CU silty to sandy unit and comparatively thinner than any other system tract. The thickest TST and HST have made the SQ-7 thickest sequence $(720 \mathrm{~m})$ in the Surma Group at the study field. In the well-2, LST deposits are absence in SQ-8, 9, 10 and 11 and they are composed of TST and HST. Most of the TSTs of these sequences are composed of silty to sandy facies and characterized by FU bell shaped retrograding para sequences. HSTs of these sequences are composed of sandstone facies. They are predominantly composed of CU funnel shaped prograding parasequence set. These system tracts have variegated thickness as shown in the Fig. 7. Finally, the SQ-12 is the topmost sequences in the Surma Group. Only LST and TST of this SQ have been interpreted. LST is composed of FU sandy rock facies and TST is composed of shaley to silty rock facies and capped by MFS-11.

In the well log and seismic profile, there is no sharp change between the lower part and upper part of the Surma 


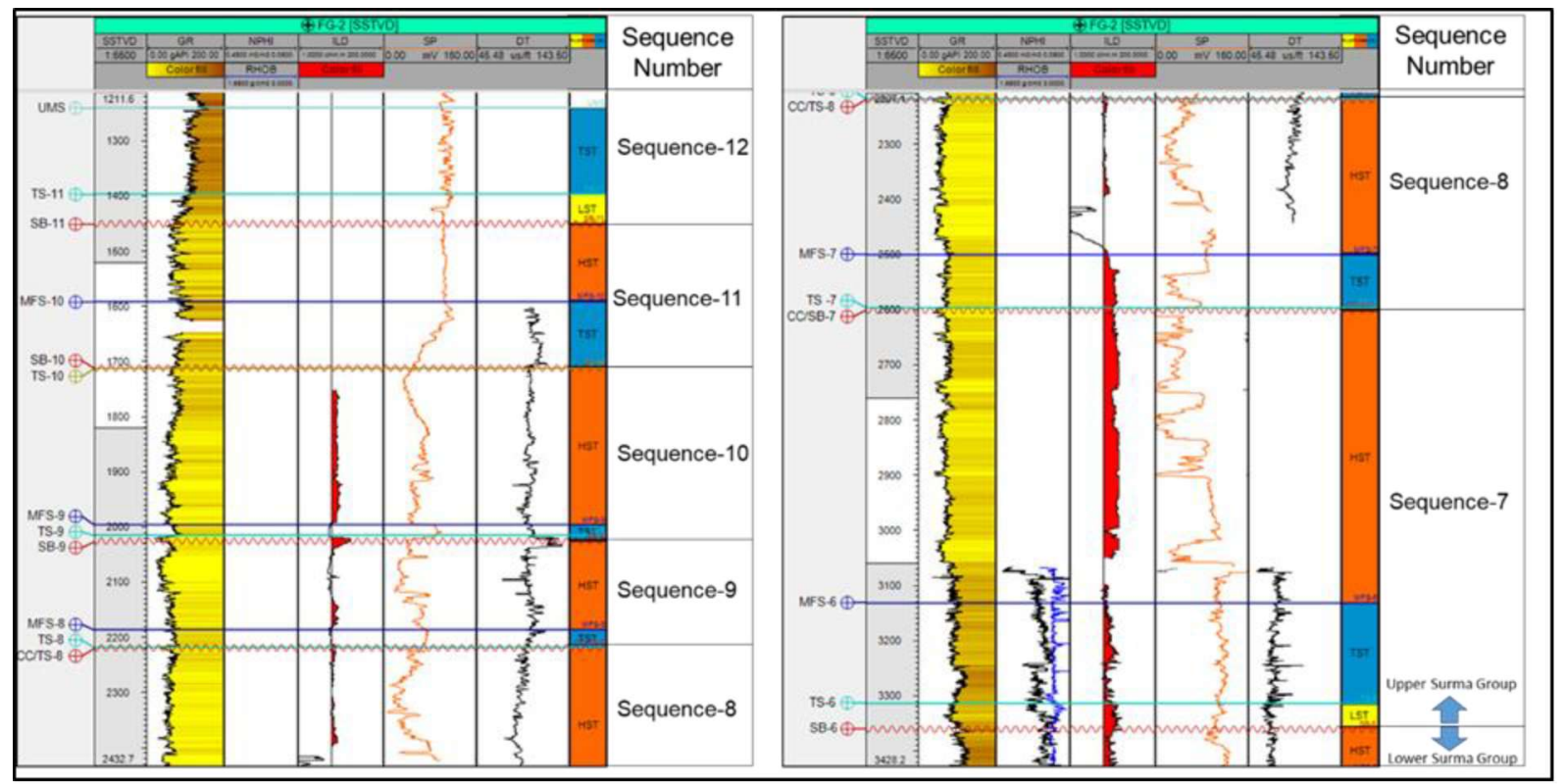

Fig. 7: Interpreted key stratigraphic surface and depositional sequence in the upper part of the Surma Group (LSTlowstand system tract, TST- transgressive system tract, HST-highstand system tract)

Group (Figs. 6, 7 and 9). However, there is a gradual change in sand shale ratio and amount of incised valley from lower to upper part in the well log profile. Upto SQ-7, the succession is shale dominated, had correlative conformity at lower part.
Sequences in the lower part are not as thick as the sequence in the upper part. Nevertheless, from sequence 7, it is sand dominate and accompanying system tracts are sandier and thicker. In the seismic profile, from SB-6 (i.e. at the base of SQ-7), incisions,

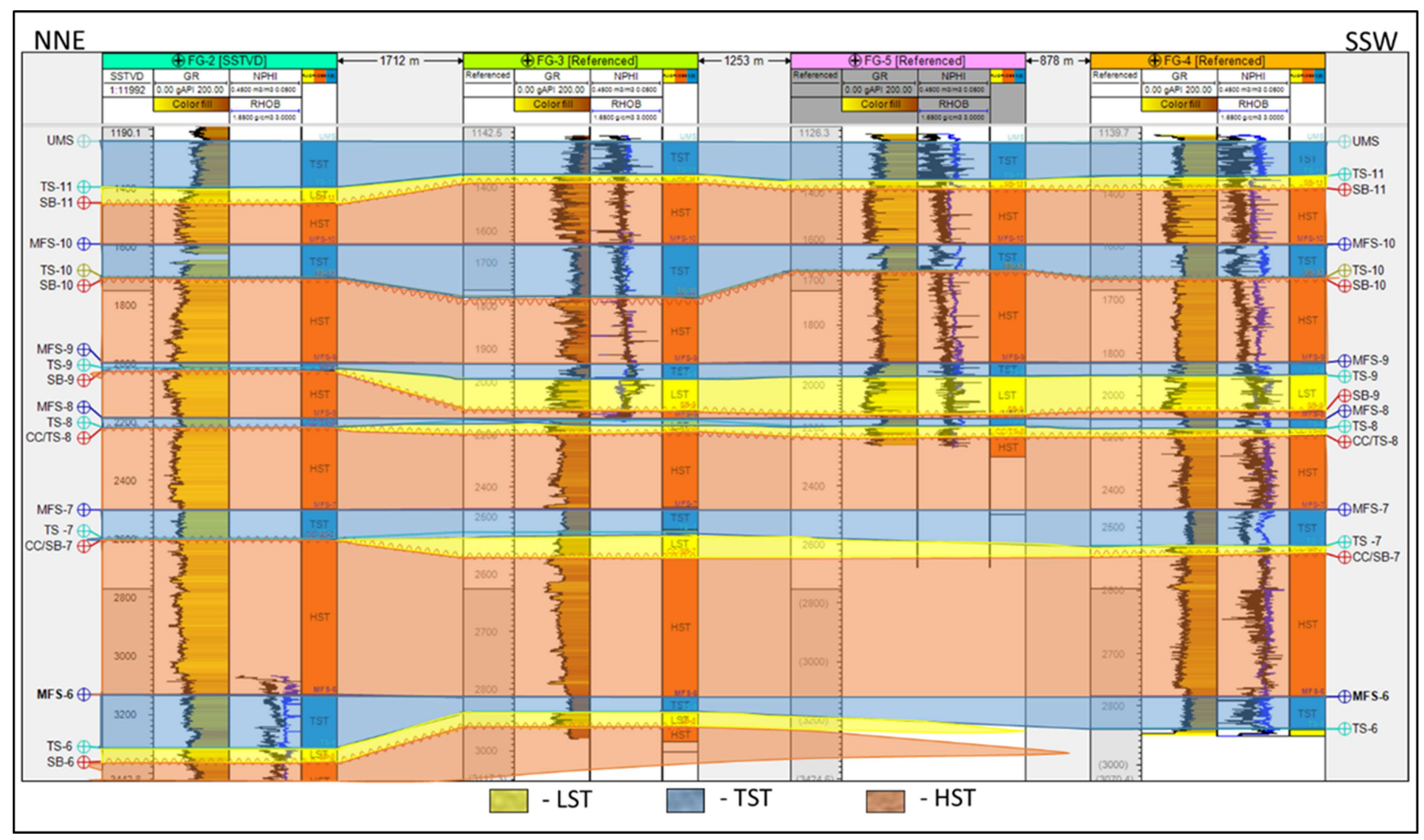

Fig. 8: Stratigraphic correlation between four well at the $\mathrm{X}$ gas field that reveals the actual configuration of strata during their deposition among four wells. 
alternation are also prominent. Even, there are no prominent reflections below SB-6 to interpret lower sequence boundaries. Hence, the SB-6 is suggested here as boundary between the Lower Surma Group and the Upper Surma Group. From SB7 to MFS-11, the succession is the Upper Surma Group and it is $2111 \mathrm{~m}$ thick in the well-2 but in other well it is about 1800 $\mathrm{m}+$. Below SB-6 at $3350 \mathrm{~m}$ in well-2, the Lower Surma Group is about $950+m$ thick. Here, the lowest boundary of the Surma Group could not be interpreted due to data scarcity.

Among four wells, only well-2 is penetrated in both Upper and Lower Surma Group. That is why identified key surfaces are correlated only in the Upper Surma Group in all wells. After flattening with MFSs, the correlation panel represents the configuration of strata during their deposition (Fig. 8). This correlation stratum is irrespective of depth and an attempt to show how they look like in their initial configuration before deformation. The displayed correlation panel has helped to compartmentalize the stratigraphic section and showed the surface geometry, extent of channel incision and their spatial amalgamation among four wells as shown in the Fig.8.
In the seismic interpretation, three strike line and nine dip line were interpreted to cover both strike and dip direction. A thrust fault was interpreted parallel to the strike line. In this research, only the up-thrown fault block was interpreted. The interpretation of strike line-5 is shown in the Fig. 9 as an example. Here the image a) is the structural interpretation without flattening and the image b) is the interpretation with flattening by MFS- 10 .

In the seismic, three strike line and nine dip line were interpreted to cover both strike and dip direction. A thrust fault was interpreted parallel to the strike line. In this research, only the up-thrown fault block was interpreted. The interpretation of strike line five is shown in the Fig. 9 as an example. Here the image a is the structural interpretation without flattening and the image $b$ is the interpretation with flattening by MFS- 10 .

Six depositional sequences in the Upper Surma Group were possible to identified in the seismic and mapped across the field from oldest to youngest SQ-7 and SQ-12 respectively. The topmost boundary was interpreted as maximum flooding surface MFS-11. The lowest boundary is the sequence boundary

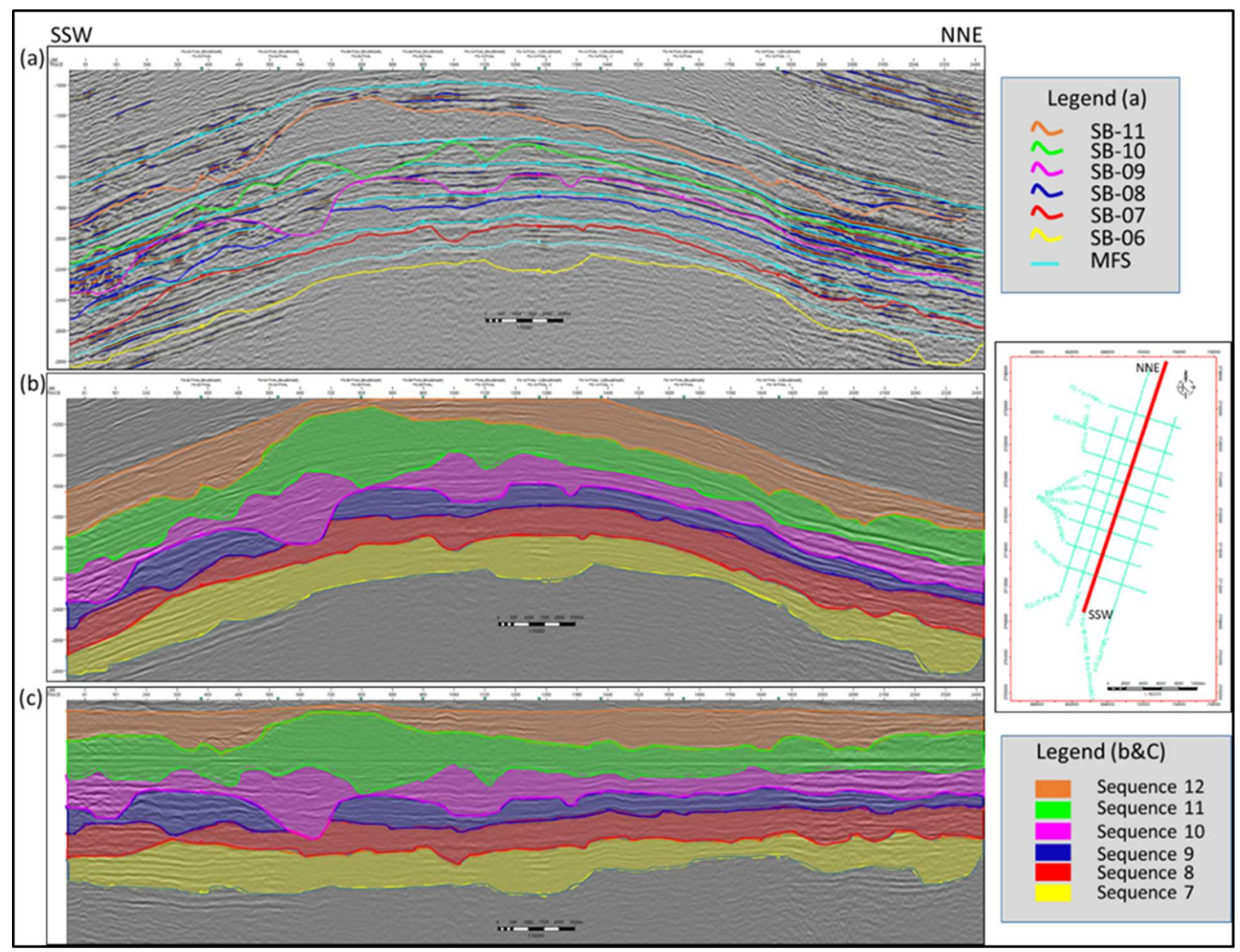

Fig. 9: Seismic sequence interpreted in the Strike line-5 at study area. (a) Depositional sequence in structural condition, (b) Same depositional sequence in stratigraphic condition. 
SB-6, which is the boundary between the Upper and the Kower Surma Group, proposed in this study. Most of the SBs show complex geometry due to incision whereas subsequent MFSs are flat. These SBs are becoming more complex upward encountering more incisions.

There are three canyons encountered by SB-6 in the SQ7. The next sequence SQ-8 has uniform thickness except the location where it is cut by overlying SB-8 and SB-9 in the SSW part. In the SQ-9, the lower boundary SB-8 has encountered two laterally amalgamated incised valley in the SSW part. This sequence is less thick as it has been significantly eroded by overlying SB-9. From middle to SSW corner, SB-9 has four significant incisions. Incised valley encountered by SB-9 in the SSW part is so extensive that it has eroded underlying SQ-9 and SQ-8 and produced vertical accretion of Lowstand channel. The dimension of this incision is of about $3507 \mathrm{~m}$ wide and $310 \mathrm{~m}$ deep though average incision in the Surma group is about $100 \mathrm{~m}$ deep. SQ-10 has variegated thickness due to the very complex incision of bounding sequence boundary SB-9 below and SB-10 above. Incision by SB-10 has increased in the middle and SSW portion resulting increased thickness of SQ-11 in this portion. Exceptionally the overlying SB-11 is larger erosional surface, which may be parallel to the strike line. The SQ-12 is the topmost sequence in the Surma group and is interpreted upto it's MFS-11.

\section{Integration of seismic and well log}

Identified key surfaces and system tracts from four wells have been matched with seismic to infer their regional configuration (Fig. 10). Well-2, 3 and 4 are very close to the seismic line -5 . Therefore, these well were tied with seismic line-5 using synthetic. This sequence stratigraphic division has given a better understanding of accommodation development and the accompanying changes in depositional sequences style, geometry. It also has given a better visualization of regional changes, pinching out and discontinuity of any system tract on seismic.

Moving to more details, in the SQ-7, though LST was extensively deposited, thickness of the LST has gradually decreased toward SSW and NNE. Later transgressive sediments were deposited upto MFS. Then, thick highstand system tract sediments pile was deposited and later eroded by overlying SB7 at the location of incised valley of SQ-8 (Fig. 8 and Fig. 10). Lowstand incised valleys have shifted towards the south and the LST sediment has only deposited within the incised valley systems and gradually pinched out within the transgressive shale. Then, highstand sediments were deposited extensively which were eroded by subsequent sequence boundaries. Similar depositional fashion followed upto SQ-10. SQ-9 is comparatively very thin in well-3, 4 and 5 due to significant erosion of its highstand system tract by overlying sequence boundary SB-9.

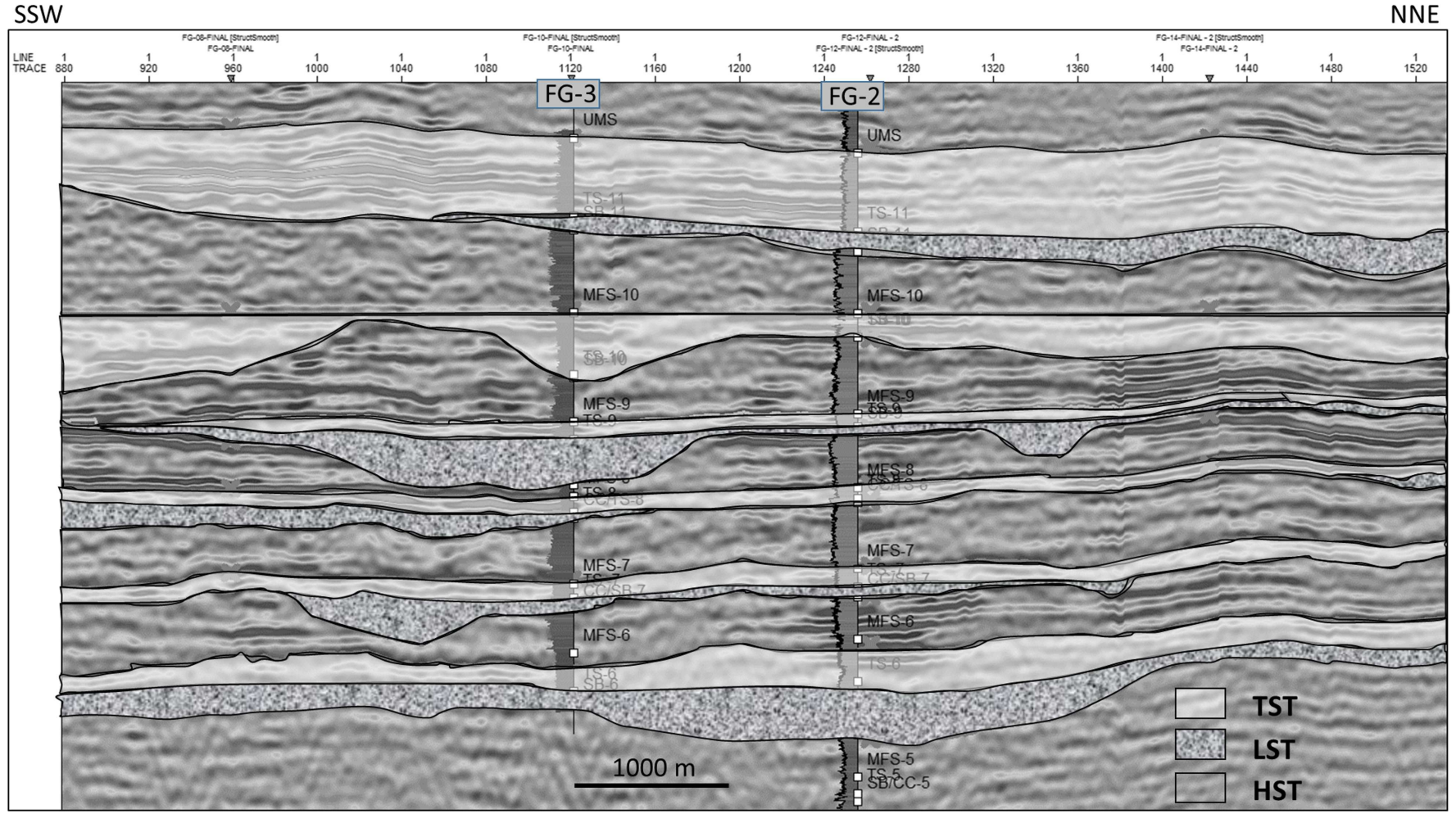

Fig. 10: Seismic to well correlation result for better understanding of the field wide configuration of depositional sequence and its comprising system tract. 
In the SQ-10, the deep incised valley in the SSW side has been penetrated by wll-3, 4 and 5 and filled with LST stacked channel deposits (Fig. 8). The overlying TST is thin across the all well whereas HST is very thick and composed of CU prograding parasequence. Exceptionally, LST has not deposited in the next sequence SQ-11 which is composed of mainly TST and HST sediments. Except in the well-3, lower bounding surfaces SB10 is the non-depositional surfaces where TS-10 directly overlies on SB 10 (Fig. 8). In well-3, it has an incision of about $100 \mathrm{~m}$ filled with TST shale with very thin layer of LST sand at the channel base. The overlying HST is predominantly composed of channel-amalgamated sandstone interpreted from well-3, 4 and 5 and its thickness has decreased toward NNW due to the erosion of overlying SB-11. Finally, in the topmost sequence, SQ-12, there are shallow but broad incision of about $50 \mathrm{~m}$ toward the NNE and filled with LST sand. The overlying TST is relatively thick capped by the topmost boundary MFS-11, which indicate the last marine transgression in the Surma Group.

\section{DISCUSSION}

The study presents a sequence stratigraphic framework to give a comprehensive scenario of depositional sequences, process and stratigraphic architecture of Neogene Surma Group in Sylhet Trough. Here, each system tracts formed a specific type of electrofacies in the specific depositional condition. Alam (1993) interpreted this Funnel Shape log motif for the Surma Group as prograding electrofacies pattern that includes (a) thin, CU sandstone facies within sand - poor sequence and bedded, (b) thin, CU interbedded sandstone and shale /mudstone facies. The FU bell shaped electrofacies for the Surma Group was interpreted as retrograding electrofacies pattern of thick, FU sandstone facies with interbedded siltstone/shale facies. This shape also suggests retrograding distributary and tidal channel, fluvial channel, point bar and deltaic channel (Chow et al., 2005). When depositional energy is essentially constant, the aggrading fluvial channel, deltaic distributaries and tidal channel show the cylindrical pattern (Posamentier and Allen, 1999; Chow et al., 2005) which is common in LST channel as well as in HST. In the Surma Group, these cylindrical shapes as aggrading electrofacies patterns that includes (a) thick blocky sandstone facies that may be stacked and (b) thick, blocky sandstone facies with interbedded sandstone/shale facies (Alam, 1993). The bow shape of coarsening and fining-upward cycle (CUFU) represents alternation of sandstone and shale lithofacies resulting from progradational and retrogradational clastic sediment (Chow et al., 2005).

Identified sequence boundaries from these facies are associated with sea level fall as well as subsidence of the Surma Basin and are considered to form type-1 sequence boundary according to Exxon model (Van Wagoner, 1988). The transgressive erosional surface or transgressive surface and maximum flooding surface within the studied section are related to the starting of the rise of sea level and maximum rise of sea level respectively (Emery and Myer, 1996). However, each third order cycle of sea level has formed a depositional sequence (Posamentier and Allen, 1999) and the interpreted twelve depositional sequences recording progressive basin fill history from shallow marine to deltaic environment near the study area (Alam, 1993). When the entire succession of Surma Group in well-2 has been matched with global sea level curve (Fig. 11), it is shown that below SB-1, there should be another sequences boundary (shown as a question mark) at the early Miocene to late Oligocene boundary. Traditionally, the lower boundary of the Surma Group that separates the Surma Group from the underlying Barail Group is placed approximately at the Oligocene-Miocene boundary (Banerji, 1984; Salt et al., 1986) and this study has revealed the similar story. The upper sequence SQ-12 was interpreted upto its MFS, which is traditionally considered as "Upper Marine Shale" (UMS) (Holtrop and Keizer, 1970) representing $230+\mathrm{m}$ thick politic sequence marking the last marine transgression. After the rise of sea level at 4.9 my when UMS deposited, there is a subsequent fall of sea level at 4.2 million years at Haq et al. (1987) sea level curve. Therefore, in the Sequence stratigraphic concept, Upper sequence boundary of SQ-12 i.e. upper boundary of Surma Group should be placed at 4.2 million years at lower to middle Pliocene boundary.

Turning to the relation of these sequences with depositional setting, we need to consider the paleodepositional environment of the Sylhet Trough. Alam (1995) suggested that the study area was dominated by the shelf to prodelta settings during Early Miocene. At the Miocene, Surma Basin was an active depocentre (Gani and Alam, 2003) and sediment direction was from the North and North East (Fig. 12). The long-term sea level was also higher than the level since middle Miocene, though short term sea level showed cyclic fluctuation (Fig. 11). Therefore, in this setting, during this time; the expected lithology should be dominated by shale with minor shoreface sand. The interpretation in this study also shows that sequences deposited during this time are shale dominated with occasional Lowstand sand and most of the sequence boundaries (SB-1, 2 and 5) at the lower sequences formed correlative conformity. However, this depositional setting was not fixed, with time the setting prograded southward (Fig. 12).

By the middle Miocene, huge sediment influxed into the basin from the north, northeast and east with continuing collision events of India with Tibetan and Burma blocks and uplift in the Himalaya and the Indo-Burma Ranges (Alam, et al., 2003). Sediment influx was also accelerated with increased gradient due to the fall of long-term global sea level since the earlier Middle Miocene. The study area prograded from outer shelf or prodelta setting to delta front setting during middle Miocene. Therefore, sequences formed during this time should be sandier then earlier sequences. We also found that from SQ-7, most of the sequences are sand dominated. Huge thickness of the SQ7 was probably due to the initiation of the fall of long-term sealevel during earlier middle Miocene. Sediment supply and accommodation might not be kept paced with each other, huge sediment dumped on the basin creating very thick SQ-7. At the 


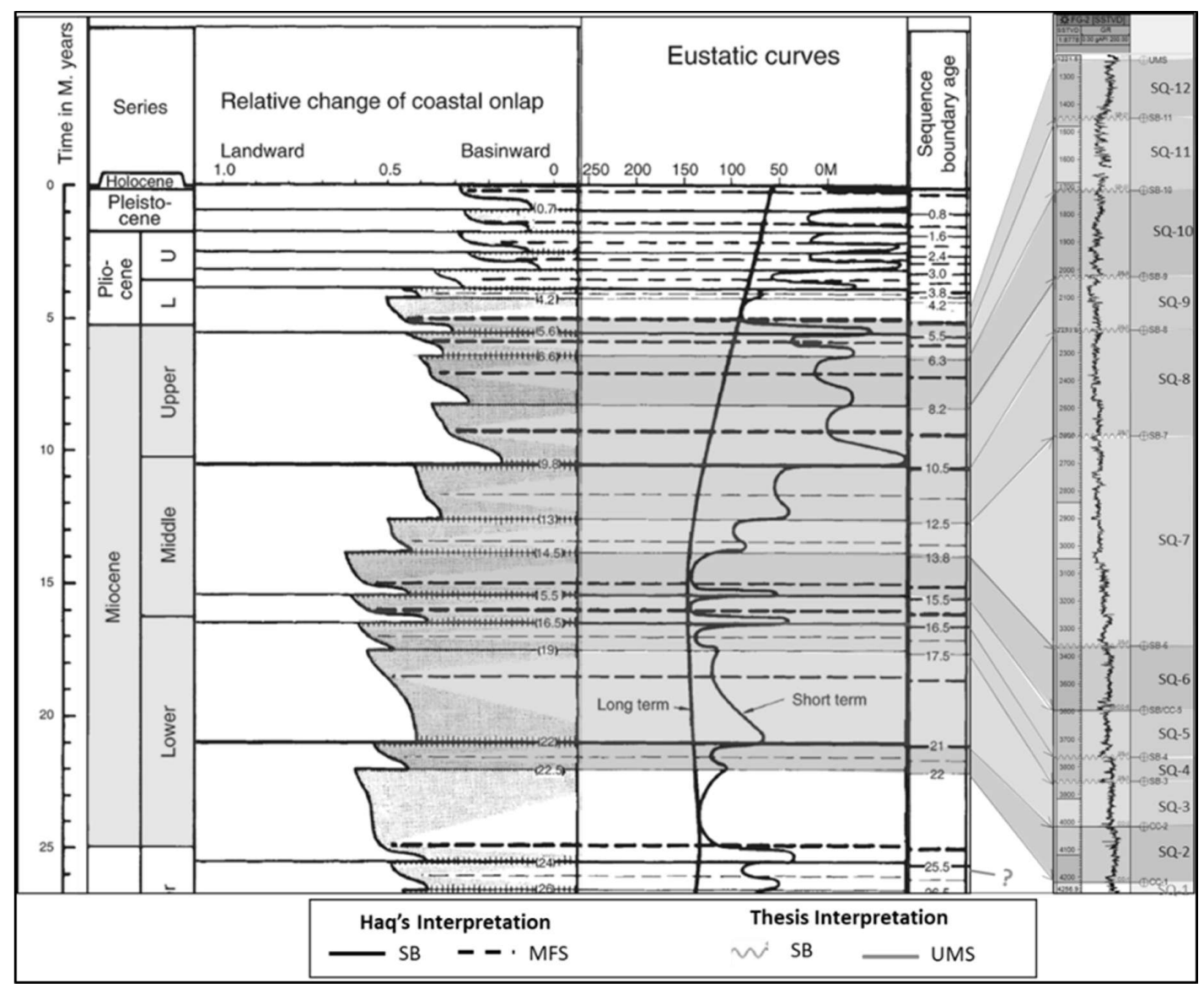

Fig. 11: Correlation of identified sequence boundaries with global sea level curve and interpreted sequence boundaries (modified after Haq et al., 1987). Identified depositional sequences (SQ) are represented with different color contrast for better understanding
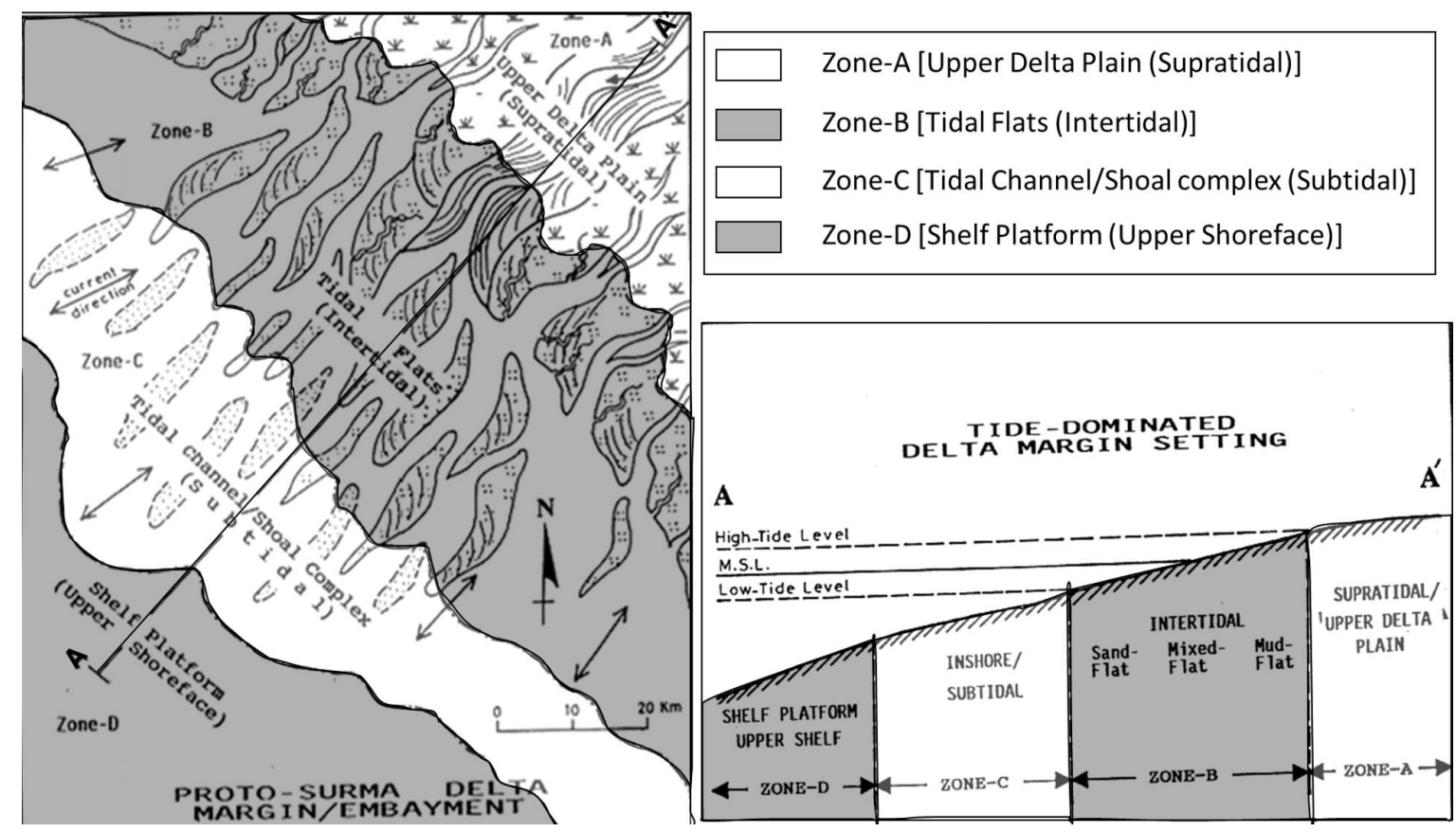

Fig. 12: Paleo-depositional environment of Surma Group succession in the Surma Basin with a NNE-SSW cross-sectional profile (modified after Alam, 1995) 
late Miocene to early Pliocene, the proto Surma delta prograded more southward and depositional setting changed from inner delta front to upper delta front to delta plain (Alam, 1993). As a result, coarse-grained sediment (channel incision) thickness of depositional sequences have increased in the upper sequences with cyclic variation of sea-level. This study also revealed that the Upper Surma group is sand dominated and incisions are frequent and deeper in the upper sequences. At the Early Pliocene (4.8 MY), there was large rise of relative sea level which is the maximum sea level rise till Holocene. This event produced shaley TST-11 capped by MFS-11. This rise is considered as last marine transgression over the Bengal Basin, which is characterized by a predominantly shaley unit named "Upper Marine Shale" (UMS) (Holtrop and Keizer, 1970). Therefore, interpreted MFS-11 in this study is equivalent to the UMS.

The analytical approach presented in this study allows better predictions of the location, architecture of sedimentary facies from limited knowledge of sedimentology, biostratigraphy and stratigraphic relationship within a sub-basin. Because of the facies pattern and vertical succession as well as the perspective juxtaposition of source, seal and reservoir facies, the lowstand system tract has excellent exploration potential (Posamentier and Allen, 1999). Coarse clastic facies of LST can be deposited in the shelf environments surrounded by pelagic or hemipelagic mud of TST that act as both hydrocarbon source and seal in the right circumstances (Posamentier and Allen, 1999). The bounding discontinuities identified from Well to Seismic integration can help both in exploration and exploitation strategies by predicting the location and geometry of stratigraphic trap, outlining the seal architecture. For example the incised valley in the SQ-10 is filled with FU LST sand but abruptly bounded below and above by highstand and transgressive marine mudstone respectively and act as a good stratigraphic trap. Any shale filled valley (for example, valley in the SQ-11) bounded at the base by shoreface sand of previous HST may act as a potential seal for this sand body.

\section{CONCLUSIONS}

The Subsurface Neogene Surma Group comprises of four major electrofacies association namely (i) Cylindrical log motif equivalent to the blocky sandstone unit, (ii) Funnel shape log motif equivalent to shaley sandstone facies (iii) Bell shaped $\log$ motif equivalent to sandy shale to silty shale facies, and (iv) Symmetrical or Bow log motif equivalent to the heterolithic facies of shale to sand to shale. These electrofacies comprise distinctive system tract of each depositional sequence which is composed of sand dominated Lowstand System Tract (LST), shale dominated Transgressive System Tract (TST) and heterolithic Highstand System Tract (HST) resulted from the short-term relative sea level changes as well as subsidence in the Surma Basin. In total, twelve depositional sequences have occurred as a repetitive depositional fashion during repetitive transgression and regression in the basin, which resulted in the sand shale alternation of the entire succession of the Surma Group. More preciously, the Surma Group is divided into sand dominated Upper Surma Group (Bokabil) 2111 m and shale dominated Lower Surma Group (Bhuban) of 950+ m. Incised valleys, channel clustering are frequent and complex in nature in the upper Surma group compared to the lower Surma Group. These changes from lower to upper sequences reflects the progradation of depositional settings from shallow marine to deltaic to fluvial environment during the deposition of entire Surma group. However, this sequence stratigraphic analysis should be done at a basin wide scale so that landward progradation, retrogradation of coastal onlap, offlap, extent of incised valley, pinch out and stratigraphic trap location can be easily resolved in the seismic profile. Therefore, in future, stratigraphy of Bengal Basin should be revised with sequence stratigraphic concept with all available data including local sea level curve, paleontological analysis and basin subsidence rate in Bengal Basin.

\section{ACKNOWLEDGEMENT}

The authors wish to thank BAPEX (Bangladesh Petroleum Exploration \& Production Company Limited) for providing datasets and giving permission to publish this article. Special thanks to Ministry of Science and Technology, Government of People's Republic of Bangladesh for providing 'NST Fellowship Program" that provided financial support during this research work.

\section{REFERENCES}

Abdullah, R., Yeasmin, R., Ameen, S.M.M., Khanam, F., and Bari, Z., 2015, 2D Structural modelling and hydrocarbon potentiality of the Sitakund Stucture, Chittagong Tripura Fold Belt (CTFB), Bengal Basin, Bangladesh. Journal of the Geological society of India, v. 85(6), pp. 697-705. https://doi.org/10.1007/s 12594-015-0266-8

Alam, M., 1989, Geology and depositional history of Cenozoic sediments of the Bengal Basin of Bangladesh. Palaeogeography Palaeoclimatology, Palaeoecolology, v. 69, pp. 125-139. https://doi.org/10.1016/00310182(89)90159-4

Alam, M., Alam, M.M., Curray, J.R., Chowdhury, M.L.R., and Gani, M.R., 2003, An Overview of Sedimentary geology of the Bengal Basin in Relation to the Regional Tectonic Framework and Basin fill History. Sedimentary Geology, v. 155, I. 3-4, pp. 179-208. https://doi.org/10.1016/S00370738(02)00180-X

Alam, M.M., 1991, Paleoenvironmental study of the Barail succession exposed in northeastern Sylhet, Bangladesh. Bangladesh Journal Science Research, v. 9, pp. 25-32.

Alam, M.M., 1993, Sedimentology and depositional environment of subsurface Neogene sediments in the Sylhet Trough, Bengal Basin: case study of the Fenchuganj and Beanibazar structures, northeastern Bangladesh. Unpublished report, Bangladesh Petroleum Institute, pp. 1-82.Alam, M. M. 1995, Sedimentology and Depositional environment of 
Bengal Basin subsurface Neogene succession based on detailed facies and electrofacies analysis: A case study of the Kailastila, Rashidpur and Bakhrabad structures in northeastern Bangladesh, NORAD project BGD-023, Bangladesh Petroleum Institute, Dhaka, 74p.

Alam, M.M. and Ferdous, M.H.S., 1996, Neogene clastic succession of the Sitapahar anticline, south-eastern Bangladesh: An example of marine-continental transition. Dhaka University Studies, v. 44(1), pp. 43-52.

Banerji, R.K., 1984, Post-Eocene biofacies, palaeoenvironments and palaeogeography of the Bengal Basin, India. Palaeogeography, Paleoclimatology, Paleoecology, v. 45, pp. 49-73. https://doi.org/10.1016/0031-0182(84)901093

Brunnschweiler, R.O., 1980, Lithostratigraphic monster in modern oil exploration. Proc. 3rd Offshore South Asia Conference, Seapex Session, Singapore.

Chow, J.J., Li, M.C., Fuh, S.C., 2005, Geophysical well log study on the paleo environment of the hydrocarbon producing zone in the Erchungchi Formation, Hsinyin, SW Taiwan. Terrestrial, atmospheric and oceanic Sciences, v. 16(3), pp. 531-545.

https://doi.org/10.3319/TAO.2005.16.3.531(T)

Emery, D. and Myers, K., 1996, Sequence Stratigraphy. B lackwell Science Ltd., Oxford. https://doi.org/10.1002/9781444313710

Evans, P., 1932, Tertiary succession in Assam. Transection Mineral Geological Institute, India, v. 27, pp. 155-260.

Gani, M.R. and Alam, M. M., 2003, Sedimentation and basinfill history of the Neogene clastic succession exposed in SE fold belt of the Bengal Basin, Bangladesh-a highresolution sequence stratigraphic approach. Sedimentary Geology, v. 155, pp. 227-270.

https://doi.org/10.1016/S0037-0738(02)00182-3

Guha, D.K., 1978, Tectonic framework and oil and gas prospect of Bangladesh., 4th Annual Conference, Bangladesh Geological Society, Dhaka, pp. 65-75.

Haq, B.U., Hardenbol, J., and Vial, P. R., 1987, Chronology of fluctuating sea levels since the Triassic. Science, v. 235(4793), pp. 1156-1167.

https://doi.org/10.1126/science.235.4793.1156

Hiller, K. and Elahi, M., 1988, Structural growth and hydrocarbon entrapment in the Surma Basin, Bangladesh. In. Wagner H.C., Wagner L.C., Wang F.F.H., Wong F.L., (Eds), Petroleum Resources of China and related subjects, Huston, Texas. Circum-Pacific Council for Energy and Mineral Resource Earth Science Series, v. 10, pp. 657-669.

Holtrop, J.F. and Keizer, J., 1970, Some aspects of the stratigraphy and correlation of the Surma Basin wells, East Pakistan. ECAFE Mineral Resource Development Service, v. 36, pp. 143-154.
Imam, B., 2013, Energy resources of Bangladesh. University Grants Commission publication, no. 151, ISBN. 984-809020-1.

Ingersoll, R. N., Graham, S. A., and Dickinson, W. R., 1995, Remnant ocean Basin, Tectonics of sedimentary basin. Blackwell, Oxford, pp. 363-391.

Johnson, S.Y. and Alam, A.M.N., 1991, Sedimentation and tectonics of the Sylhet Trough, Bangladesh. Geological Society of America Bulletin, v. 103, pp. 1513-1527. ht t p s : / / d o i.org/ 10 . $1130 / 0016$ 7606 (1991) $103<1513: \mathrm{SATOT} \mathrm{S}>2.3$. CO;2

Khan, M.A.M., Ismail, M., and Ahmed, M., 1988, Geology and hydrocarbon prospects of Surma Basin, Bangladesh, Proc. 7th offshore Southeast Asia conference, Singapore, pp. 354-387.

Khanam, F., 2017, Sedimentologic, Sequence Stratigraphic and Diagenetic History of the Neogene Sedimentary Succession in the Sylhet Trough, Bengal Basin, Bangladesh. PhD thesis, Jahangirnagar University, Savar, Dhaka, Bangladesh, $164 \mathrm{p}$.

Lietz, J.K. and Kabir, J., 1982, Prospects and constraints of oil exploration in Bangladesh, Proc. 4th offshore Southeast Asia conference, Singapore, pp. 1-6. https://doi.org/10.2118/10444-MS

Merkel, R.H., 1979, Well Log Formation Evaluation. American Association of Petroleum Geologists, $82 \mathrm{p}$.

Mirkhamidov, S. and Mannan, F.M., 1981, Nature of gravity field and its relation with Geotectonic of Bangladesh, Petrobangla Report, 51p.

Mitchum, R.M., Jr, Vial P.R., 1977, Seismic Stratigraphy and Global changes of sea-level, Part-7, stratigraphic interpretation of Seismic reflectionpattern in depositional sequences. In: C. E. Payton, Ed., Seismic StratigraphyApplications to Hydrocarbon Exploration, AAPG Memory, Tulsa, v. 26, pp. 135-144.

Najman, Y., Bickle, M., Bou Dagher-Fadel, M., Carter, A., Garzanti, E., Paul, M., Wijbrans, J., Willett, E., Oliver, G., Parrish, R., Akhter, S.H., Allen, R., Ando, S., Chisty, E., Reisberg, L., and Vezzoli, G., 2012, The record of Himalayan erosion preserved in the sedimentary rocks of the Hatia Trough of Bengal Basin and the Chittagong Hill Tarcts, Bangladesh. Basin Research, v. 24, pp. 1-21. https://doi.org/10.1111/j.1365-2117.2011.00540.x

Parvin, A., Rahman, M.J., and Woobaidullah, A.S.M., 2019, Petroleum prospect analysis and new gas horizon detection at Fenchuganj Gas field in the Surma Basin, Bangladesh: An application of the sequence stratigraphic concept. Marine and Petroleum Geology, Elsevier, v. 102, pp. 786-799. https://doi.org/10.1016/j.marpetgeo.2019.01.033

Posamentier, H.W. and Allen, G.P., 1999, Siliciclastic sequence stratigraphy: concepts and applications., SEPM (Society 
for sedimentary Geology) Tulsa, 210p.

Reimann, K.U., 1993, The Geology of Bangladesh. Berlin, Gebruder Borntraeger, 160p.

Rider, M., 2002, The geological interpretation of well logs. 2nd edition, Whittkles publishing, Caithness, 280p.

Salt, C.A., Alam, M.M., and Hossain, M.M., 1986, Bengal Basin-Current exploration of Hinge Zone of Southwestern Bangladesh. Proceed. 6th Offshore Southeast Asia conf, Singapore, pp. 55-67.

Serra, O., Sulpice, L., 1975, Sedimentological analysis of shalesand series from well logs: Transactions of the SPWLA 16th Annual Logging Symposium, paper W.

Shamsuddin, A.H.M. and Abdullah, S.K.M., 1997, Geologic evolution of the Bengal Basin and its implication in hydrocarbon exploration in Bangladesh. Indian Journal of Geology, v. 69, no. 1, pp. 93-121.
Sultana, D.N. and Alam, M.M., 2001, facies analysis of the Neogene Surma Group succession in the subsurface of the Surma Basin, Bengal Basin, Bangladesh. Bangladesh Geoscience Journal, v. 6, pp. 53-74.

Vail, P.R., Mitchum, R.M., and Thompson, S., 1977, Seismic Stratigraphy and Global Changes of Sea Level, Part 3: Relative Changes of Sea Level from Coastal Onlap, In: C. E. Payton, Ed., Seismic Stratigraphy-Applications to Hydrocarbon Exploration, AAPG Memoir, v. 26, pp. 63-81.

Van Wagoner, J.C., Mitchum, R.M., Campion, K.M., and Rahman, V.D., 1990, Siliciclastic Sequences Stratigraphy in Well Logs, Core and Outcrops: Concepts for Highresolution Correlation of Time and Facies. American Association of Petroleum Geologists Methods in Exploration Series no. 7, 55p. 